\title{
Fixation of critical level of available magnesium in soils of maize growing tracts of Pudukkottai district of Tamil Nadu, India
}

\author{
P. Sankaralingam* and P. Malarvizhi \\ Department of Soil Science and Agricultural Chemistry, Tamil Nadu Agricultural University, \\ Coimbatore-3, India \\ *Corresponding author
}

A B S T R A C T

Keywords

Maize,

Magnesium,

Grain Yield,

Critical limit

Article Info

Accepted:

20 January 2020

Available Online:

10 February 2020
In order to assess the response of maize to applied $\operatorname{Mg}(0,5,10,15,20$ and $25 \mathrm{~kg} \mathrm{ha}^{-1}$ ) for arriving at the optimum $\mathrm{Mg}$ level for this crop and to fix the critical limit of $\mathrm{Mg}$, field experiments were conducted in 14 farmer's holdings at Pudukkottai district with Hybrid Maize (NK 6240) as a test crop by adopting the Cate and Nelson graphical and statistical (analysis of Variance method) method of critical limit fixation. The soil Magnesium (Mg) content varied from 24 to $408 \mathrm{mg} / \mathrm{kg}$ and the Bray's percent yield varied from 76.2 to 95.0 and these were used to fix the critical limit of Magnesium $(\mathrm{Mg})$ in soil. The $\mathrm{R}^{2}$ value ranged from 0.09 to 0.88 and the postulated critical level of $\mathrm{Mg}$ in soil corresponding to the highest $\mathrm{R}^{2}(0.88)$ was recorded as $84 \mathrm{mg} / \mathrm{kg}$.

\section{Introduction}

Magnesium $(\mathrm{Mg})$ is a basic plant nutrient that is excessively as often as possible disregarded. Despite the fact that enduring of essential and secondary minerals may give sufficient magnesium in certain soils, there are a few soils that benefit by magnesium increases. There are different solvent and gradually dissolvable magnesium sources accessible to meet the crop needs. The world's outside contains about 2.0 percent magnesium, to a great extent as magnesium containing minerals (Mikkelsen, 2010). The stockpile of accessible magnesium has been or is being exhausted in certain soils through draining, plant take-up and removal forms. Among all the secondary nutrients $\mathrm{Mg}$ assume indispensable role in crop development. The $\mathrm{Mg}$ prerequisite for ideal plant growth is 1.5$3.5 \mathrm{~g}$ per $\mathrm{kg}$ in vegetative parts, and $\mathrm{Mg}$ fixations in soil arrangements lie between 125 $\mu \mathrm{mol} \mathrm{L}{ }^{-1}$ and $8.5 \mathrm{mmol} \mathrm{L}^{-1}$, values adequate to support plant development (WanliGuo et al., 2016).

Among the cereal crops, Maize and Wheat are highly susceptible to $\mathrm{Mg}$ deficiency. 
Magnesium is an integral component of large number of enzymes viz., alcohol dehydrogenase, carbonic anhydrase, $\mathrm{Cu}-\mathrm{Mg}$ superoxide dismutase, alkaline phosphatase, phospholipases, carboxy peptidases and RNA polymerases. In the enzymes, $\mathrm{Mg}$ has three main functions as catalytic, co-catalytic and structural functions. Magnesium plays an important role in DNA and RNA metabolism, cell division and protein synthesis. The most distinct $\mathrm{Mg}$ deficiency symptoms are stunted growth and little leaf which are presumably related to disturbance in the metabolism of auxin and indoleacetic acid in particular. It is also required for maintaining the integrity of biomembranes in the plants (Hafeez et al., 2013). Magnesium is absorbed as the $\mathrm{Mg}^{2+}$ ion and is mobile in plants, moving from the older to the younger leaves. It leaches from the soil like calcium and potassium. Low cation exchangeable capacity (CEC), cation competition and particularly long term imbalanced fertilization of nitrogen, phosphorus and potassium (NPK) are possible reasons of Magnesium $(\mathrm{Mg})$ deficiency in highly weathered, sandy and acidic soils.(Sreedhara and Cowan, 2002; Cakmak and Yazici, 2010; Gransee and Fuhrs, 2013).So, as to know the present status of soil accessible $\mathrm{Mg}$ in soils and for appropriate suggestion of manures to the ranchers, it is fundamental to refine as far as possible for $\mathrm{Mg}$ in the of Maize developing regions of Pudukkottai in Tamil Nadu, since Maize is a staple nourishment crop developed widely in Tamil Nadu.

\section{Materials and Methods}

In order to establish the fixing of critical level of available magnesium in soils of maize growing tracts in Pudukkottai district of Tamil Nadu, 14 field experiments were conducted with six treatments $(0,5,10,15,20$ and $25 \mathrm{~kg}$ $\mathrm{ha}^{-1}$ ) in RBD with Hybrid Maize (NK 6240) as a test crop. The experimental fields were ploughed with disc plough once, followed by cultivator ploughing twice, after spreading FYM till a fine tilth were obtained. Ridges and furrows were provided with sufficient irrigation channels. The ridges were formed at required length and $60 \mathrm{~cm}$ apart. The seeds were sown at $25 \mathrm{~cm}$ apart $(60 \times 25 \mathrm{~cm}$ spacing). Dibbled the seeds at a depth of $4 \mathrm{~cm}$ in beds in which fertilizers are placed in spots and covered with soil. A blanket recommendation of 250:75:75 NPK kg/ha for hybrid maize was adopted. In the field experiments, the required quantity of $\mathrm{Mg}$ was applied as per the schedule to all the treatments as $\mathrm{MgSO}_{4}$ and also without application of $\mathrm{Mg}$ fertilizer was maintained as control. The critical limit of nutrient in the soils was fixed by adopting statistical methods proposed by Cate and Nelson (1965) and Cate and Nelson (1971).

\section{Results and Discussion}

Cate and Nelson (1965) developed a graphical method for portioning the percentage yield versus soil available $\mathrm{Mg}$ using the scatter plotting in a graph sheet. The soil available $\mathrm{Mg}$ content varied from 24 to $408 \mathrm{mg} / \mathrm{Kg}$ and the Bray's percent yield varied from 76.2 to 95.0 and these were used to fix the critical limit of Mg in Soil. By using these values, the scatter diagrams were plotted on a graph sheet with soil available $\mathrm{Mg}$ in $\mathrm{X}$-axis and Bray's percent yield in Y-axis and hence the critical limit has been fixed. The plot of Bray's percent yield against soil $\mathrm{Mg}$ revealed the value $84 \mathrm{mg} / \mathrm{Kg}$ as the Critical Limit of $\mathrm{Mg}$ in Soil.

In the statistical method also, soil available $\mathrm{Mg}$ content and Bray's percent yield were considered for critical level fixation. The soil Magnesium $(\mathrm{Mg})$ content varied from 24 to $408 \mathrm{mg} / \mathrm{kg}$ and the Bray's percent yield varied from 76.2 to 95.0 and these were used to fix the critical limit of Magnesium (Mg) in soil. The $\mathrm{R}^{2}$ value ranged from 0.09 to 0.88 and the postulated critical value of $\mathrm{Mg}$ in soil 
corresponding to the highest $\mathrm{R}^{2}(0.88)$ was recorded as $84 \mathrm{mg} / \mathrm{kg}$.

In the present investigation, a critical level of $84 \mathrm{mg} \mathrm{kg}^{-1} \mathrm{Mg}$ in soil was determined by graphical method (Cate et al., 1965) as well as by statistical procedure (Nelson and Anderson, 1975) respectively. Hence, the maize soils of Pudukottai district which analyze for the plant available $\mathrm{Mg}$ of less than $84 \mathrm{mg} \mathrm{kg}^{-1}$ will show profitable response to $\mathrm{Mg}$ fertilization.

In the present study also, all the soils below this critical levels markedly responded to the $\mathrm{Mg}$ fertilizer application and a declining response was noted by the application $\mathrm{Mg}$ fertilizers in the soils with higher $\mathrm{Mg}$ content (higher than the critical limit). Research conducted by Abunyewa and Mercer-Quarshie (2004) on the response of maize to magnesium and zinc application showed that the maize grain yield increased 0.6 to 16.5 per cent. Szulc et al., (2008) based on their studies in maize found that application of magnesium with sulphur caused a significant increase in maize grain yield (5.7 to $10.7 \%)$. The studies conducted by Noor et al., (2015) showed that the maize yield was the highest at $20 \mathrm{~kg} \mathrm{Mg}$ $\mathrm{ha}^{-1}$.

Table.1 Critical limit of soil available $\mathrm{Mg}(\mathrm{mg} / \mathrm{kg})$ using Cate -Nelson Statistical method

\begin{tabular}{|c|l|c|c|c|c|c|}
\hline S.No & Soil Location & Soil available $\mathbf{M g}(\mathbf{m g} / \mathbf{k g})$ & *PCL & Bray's \% yield & **CSS & $\mathbf{R}^{\mathbf{2}}$ \\
\hline 1 & Pallathividuthi & 24 & & 76.2 & & \\
\hline 2 & Vembankudi & 24 & 36 & 80.6 & 339.7 & 0.37 \\
\hline 3 & Vamban & 48 & 48 & 79.5 & 236.8 & 0.56 \\
\hline 4 & Melakottai & 48 & 54 & 85.0 & 237.6 & 0.56 \\
\hline 5 & Pallathividuthi & 60 & 66 & 83.9 & 197.9 & 0.63 \\
\hline 6 & Thatchinapuram & 72 & 78 & 83.8 & 139.9 & 0.74 \\
\hline 7 & Mikelpatty & $\mathbf{8 4}$ & $\mathbf{8 4}$ & $\mathbf{8 4 . 0}$ & $\mathbf{6 7 . 4}$ & $\mathbf{0 . 8 8}$ \\
\hline 8 & Visalur & 84 & 111 & 92.7 & 169.6 & 0.69 \\
\hline 9 & Adhanakottai & 138 & 141 & 93.5 & 264.8 & 0.51 \\
\hline 10 & Melur & 144 & 186 & 93.2 & 334.2 & 0.38 \\
\hline 11 & Thudaiyur & 228 & 234 & 95.0 & 419.0 & 0.22 \\
\hline 12 & Thudaiyur & 240 & 312 & 92.5 & 454.7 & 0.16 \\
\hline 13 & Kudumianmalai & 384 & 396 & 93.0 & 490.7 & 0.09 \\
\hline 14 & Kudumianmalai & 408 & & 94.5 & & \\
\hline
\end{tabular}

The critical limits of plant available soil $\mathrm{Mg}$ as per the graphical and statistical methods were found to be $84 \mathrm{mg} \mathrm{kg}^{-1}$. Based on this critical limit considerable study area in Pudukkottai district were deficient in available $\mathrm{Mg}$ cautioning the need for $\mathrm{Mg}$ fertilization at regular interval to maximize yield. Otherwise, the deficiency of $\mathrm{Mg}$ will gradually become a major constraint to the productivity of crops.
Hence, the maize growing soils of Pudukkottai district which analyze for the plant available $\mathrm{Mg}$ of less than $84 \mathrm{mg} \mathrm{kg}^{-1}$ will show profitable response to $\mathrm{Mg}$ fertilization. This information will be of immense use to identify the degree of $\mathrm{Mg}$ deficiency and extent of deficient areas for planning and formulating $\mathrm{Mg}$ fertilization programme keeping the entire maize growing soils of Pudukkottai district as a unit. Further, 
the findings of the present investigation underline the importance of complete soil testing for secondary nutrients along with macronutrients which will pave the way for adoption of site-specific secondary nutrient management for maize.

\section{Acknowledgements}

We sincerely acknowledge the input and support provided by field staffs during trial management, sampling and analysis. We are very thankful to farmers from Pudukkottai district for providing experimental field and TNAU hosting analytical laboratory.

\section{References}

Abunyewa A.A. and H. Mercer-Quarshie. 2004. Response of Maize to Magnesium and Zinc Application in the Semi-Arid Zone of West Africa. Asian Journal of Plant Sciences, 3: 1-5.

Cakmak, I., and Yazici, A. M. 2010. Magnesium: a forgotten element in crop production. Better Crops 94, 23-25.

Cate, R.B. and Nelson L.A.1971. A simple statistical procedure for partitioning soil test correlation data into two classes. Soil Sci Soc Am Proc 35: 658-660

Cate, R.B. and Nelson, L.A. 1965. A rapid method of correlation of soil test analysis with plant response data. Int Soil Test, Tech Bull 1, 15 pp.

Cate, T.R., R.D. Rossen, R.G. Douglas Jr., W .T. Butler, R.B. Couch. 1965. The role of nasal secretion and serum antibody in the rhinovirus common cold. Am. J. Epidemiol., 84, pp. 352-363

Gransee, A. and Führs, H. 2013. Magnesium mobility in soils as a challenge for soil and plant analysis, magnesium fertilization and root uptake under adverse growth conditions. Plant Soil 368, 5-21. doi: 10.1007/s11104012-1567-y

Hafeez, B. Y. M. Khanif, A. W. Samsuri, O. Radziah, W. Zakaria \& M. Saleem. 2013. Direct and Residual Effects of Zinc on Zinc-Efficient and Zinc-Inefficient Rice Genotypes Grown under Low-Zinc-Content Submerged Acidic Conditions, Communications in Soil Science and Plant Analysis, 44:15, 2233-2252, DOI: $10.1080 / 00103624.2013 .803558$.

Mikkelsen, R. (2010). Soil and fertilizer magnesium. Better Crops 94, 26-28.

Sreedhara, A. and Cowan, J. 2002. Structural and catalytic roles for divalent magnesium in nucleic acid biochemistry. Biometals 15, 211-223.

Szulc, P., Kiel, D. P., \& Delmas, P. D. (2008). Calcifications in the abdominal aorta predict fractures in men: MINOS study. Journal of Bone and Mineral Research, 23(1), 95-102.

Wanli Guo, Hussain Nazim, Zongsuo Liang, Dongfeng Yang. 2015. Magnesium deficiency in plants: An urgent realistic problem, The Crop Journal 4(2): 117126.

\section{How to cite this article:}

Sankaralingam, P. and Malarvizhi, P. 2020. Fixation of critical level of available magnesium in soils of maize growing tracts of Pudukkottai district of Tamil Nadu, India. Int.J.Curr.Microbiol.App.Sci. 9(02): 3017-3020.doi: https://doi.org/10.20546/ijcmas.2020.902.346 